\title{
The Influence of $\mathbf{C}: \mathbf{N}$ Ratio in the Growth Medium on the Cellular Composition and Regulation of Enzyme Activity in Hyphomicrobium $\mathrm{X}$
}

\author{
By M. G. DUCHARS AND MARGARET M. ATTWOOD* \\ Department of Microbiology, University of Sheffield, Sheffield S10 2TN, UK
}

(Received 10 November 1988; accepted 22 December 1988)

\begin{abstract}
The regulation of the enzymes associated with one-carbon metabolism and the assimilation of nitrogen, together with the cellular composition of Hyphomicrobium X, were investigated. The effect of changing the methanol-carbon concentration with the $\mathrm{NH}_{4}^{+}$-nitrogen concentration remaining constant $(C: N$ ratio) in the medium during chemostat growth at a constant dilution rate was studied. As the medium changed from a $\mathrm{C}$-limitation to a dual $\mathrm{C}$ - and $\mathrm{N}$ - and finally a $\mathrm{N}$-limitation, the culture gradually passed through three definite growth phases. In response to these environmental conditions the cellular composition and the specific enzyme activity patterns changed. The $\mathrm{C}$-content of the cells changed very little. The $\mathrm{N}$-and protein-content was constant over $\mathrm{C}$-limiting conditions, but under dual $\mathrm{C}$ - and $\mathrm{N}$-limiting and $\mathrm{N}$-limiting conditions an accumulation of poly- $\beta$-hydroxybutyrate (PHB) occurred and as a consequence the $\mathrm{N}$-content and protein-content of the cells decreased. The enzyme associated with $\mathrm{N}$ assimilation during $\mathrm{C}$-limitation was an $\mathrm{NADP}^{+}$-dependent glutamate dehydrogenase which was replaced by the high affinity glutamine synthetase and glutamate synthase pathway immediately the $\mathrm{NH}_{4}^{+}-\mathrm{N}$ concentration in the medium became limiting. Similarly the specific activity of methanol dehydrogenase, which was high during $\mathrm{C}$-limiting conditions, dropped to a low level as the $\mathrm{NH}_{4}^{+}-\mathrm{N}$ concentration decreased. Finally carbon balances were constructed throughout the experiment which showed that irrespective of the $\mathrm{C}: \mathrm{N}$ ratio in the medium during $\mathrm{C}$-limitation, the methanol-carbon was fluxed into biomass and $\mathrm{CO}_{2}$ only; during dual limitation the carbon was channelled into biomass, $\mathrm{CO}_{2}$ and $\mathrm{PHB}$; and finally when the growth was in the presence of excess carbon no methanol-carbon was directed into overmetabolite production but, instead, the excess carbon was oxidized through the dissimilatory pathway.
\end{abstract}

\section{INTRODUCTION}

Hyphomicrobium $\mathrm{X}$ has been shown to be a facultative methylotroph which assimilates $\mathrm{C}_{1}$ carbon via the $\mathrm{ICL}^{-}$serine pathway and obtains energy using the linear oxidation sequence of dehydrogenases to convert the substrate to $\mathrm{CO}_{2}$ and water (Harder et al., 1973; Harder \& Attwood, 1975). Subsequent studies using carbon-limited chemostat cultures grown on methylamine showed that the carbon was fluxed into biomass and $\mathrm{CO}_{2}$, and that the $\mathrm{C}_{1}$ assimilatory enzymes were co-ordinately regulated in a manner independent of the dissimilatory enzymes (Brooke \& Attwood, 1985).

Like many non-methylotrophic bacteria Hyphomicrobium $\mathrm{X}$ can grow on a range of $\mathrm{N}$-sources (Harder \& Attwood, 1978) and can express both NADP+-dependent glutamate dehydrogenase

\footnotetext{
Abbreviations: GDH, glutamate dehydrogenase; GS, glutamine synthetase; GOGAT, glutamate synthase; PBH, poly- $\beta$-hydroxybutyrate.
} 
(GDH) activity and the high affinity glutamine synthetase : glutamate synthase (GS: GOGAT) pathway for $\mathrm{N}$-assimilation. Elevated levels of $\mathrm{NADP}^{+}$-dependent $\mathrm{GDH}$ were expressed when the $\mathrm{N}$-source was ammonium sulphate or methylamine and present in excess. When the $\mathrm{N}$ source was nitrate or in limited supply the GDH activity decreased and the level of GS:GOGAT activity in the cells was increased (Brooke et al., 1987). This paper reports the effect of changing the $\mathrm{C}: \mathrm{N}$ ratio in the medium on the cellular composition, the regulation of the enzymes associated with both the $\mathrm{C}_{1}$-metabolism and $\mathrm{N}$-assimilation and the pathways through which the methanol-carbon is fluxed when the cells are grown under excess carbon.

\section{METHODS}

Organisms, cultural conditions and growth. Hyphomicrobium $\mathrm{X}$ was maintained and grown as previously described (Marison \& Attwood, 1982). The organism was grown in a chemostat with a working volume of 2.51. The $\mathrm{NH}_{4}^{+}-\mathrm{N}$ content $\left(69.9 \mathrm{mg}^{-1}\right)$ in the medium remained constant whilst the concentration of methanol was progressively increased $\left(0.24\right.$ to $\left.1.08 \mathrm{~g} \mathrm{l}^{-1}\right)$ to give the varying $\mathrm{C}: \mathrm{N}$ ratios. The temperature was maintained at $30^{\circ} \mathrm{C}$, the $\mathrm{pH}$ adjusted to 6.9 by the addition of sterile $\mathrm{NaOH}(1 \mathrm{M})$ and the dissolved oxygen in the medium maintained above $50 \%$ saturation by the addition of sterile air and constant stirring ( 460 r.p.m.). The chemostats were inoculated with cells grown to the mid-exponential phase of growth in batch culture in media with the same $\mathrm{C}: \mathrm{N}$ ratio. The cells were considered to be in a steady state when not less than five culture volumes had occurred with the same optical density. Growth was monitored by measuring the optical density at $430 \mathrm{~nm}$.

Residual substrate concentrations. Samples were rapidly withdrawn from the chemostat, the cells were immediately removed and the concentrations of the substrates in the cell-free medium measured. Methanol was measured using gas chromatography (Pye-Unicam) equipped with a flame ionization detector and a glass column $(1.5 \mathrm{~m} \times 4 \mathrm{~mm})$ packed with Poropak Q. Nitrogen $\left(60 \mathrm{ml} \mathrm{min}^{-1}\right)$ was the carrier gas and the column temperature was $160^{\circ} \mathrm{C}$. Ethanol was used as an internal standard. $\mathrm{NH}_{4}^{+}-\mathrm{N}$ was measured by the method of Tetlow \& Wilson (1964).

Biomass. Cells $(50 \mathrm{ml})$ were collected, washed once with an equal volume of distilled water, resuspended in a minimal volume of water $(2-3 \mathrm{ml})$, placed in a pre-weighed container and dried to constant weight at $105^{\circ} \mathrm{C}$. Triplicate samples varied by less than $\pm 3 \cdot 5 \%$.

Elemental and cellular composition. To determine the elemental composition, the cells were removed from steadystate cultures, centrifuged, washed once with distilled water and freeze dried. After subsequent drying over $\mathrm{P}_{2} \mathrm{O}_{5}$ in vacuo the cells were sent for elemental analysis (Chemistry Department, Sheffield University). Poly- $\beta$ hydroxybutyrate (PHB) was measured using a modified method based on the findings of Law \& Slepecky (1961). PHB was quantitatively converted to crotonic acid. The molar absorption coefficient of $1.56 \times 10^{-4} \mathrm{M}^{-1} \mathrm{~cm}^{-1}$ was used. The mean $M_{\mathrm{r}}$ of the polymer $\left(\mathrm{C}_{4} \mathrm{H}_{6} \mathrm{O}_{2}\right)=86$ was assumed (Herbert et al., 1971). Protein concentrations in both whole cells and cell-free extracts were measured by the Lowry method. Bovine serum albumin was the standard.

Gas analysis. Oxygen and carbon dioxide concentrations in the outflow gas from chemostat cultures were measured with Servomax 570A and Servomax PA404 oxygen and carbon dioxide analysers respectively. The analysers were set to zero using oxygen-free nitrogen and then to maximum value of $20.9 \%$ and $5.0 \%$ with air or $5.0 \% / 95 \%$ carbon dioxide/nitrogen mixture respectively.

Preparation of cell-free extracts. At each steady state, samples $(600 \mathrm{ml})$ were withdrawn from the chemostats, centrifuged ( $5000 \mathrm{~g}$ for $5 \mathrm{~min}$ ) and washed once with $50 \mathrm{mM}$-Tris/ $\mathrm{HCl}$ buffer $\mathrm{pH} 7 \cdot 5$. Ice-cold cell suspensions ( $1 \mathrm{~g}$ wet weight in $4 \mathrm{ml}$ ) were disrupted by sonication as previously described (Duchars \& Attwood, 1987).

Enzyme assays. All enzyme activities were measured at $30^{\circ} \mathrm{C}$ using a double beam recording spectrophotometer. The observed enzyme rates were proportional to the amount of cell-free extract added. One unit of enzyme activity is defined as the amount of enzyme that produces $1 \mu \mathrm{mol}$ product or coenzyme reduced/oxidized min $^{-1}$. Enzyme activities were measured using previously reported methods. Glutamate dehydrogenase (NADP ${ }^{+}$-dependent) (EC 1.4.1.3) and glutamine 2-oxoglutarate aminotransferase (glutamate synthase) (EC 1.4.1.14) were assayed as described by Meers et al. (1970). Glutamine synthetase (EC 6.3.1.2) activity was measured both in the biosynthetic direction and as the $\gamma$-glutamyltransferase assay (Bender et al., 1977). A standard curve was constructed using commercially available $\gamma$-glutamyl hydroxamate. The percentage adenylylation was calculated on the basis of the $\gamma$-glutamyltransferase activity in the presence and absence of $\mathrm{MgCl}_{2}(60 \mathrm{mM})$ (Shapiro \& Stadtman, 1970). Methanol dehydrogenase (EC 1.1.99.8) was assayed by the method of Anthony \& Zatman (1964), formate dehydrogenase (NAD ${ }^{+}$-dependent (EC 1.2.1.2) by that of Johnson \& Quayle (1964) as modified by Harder et al. (1973), L-serine : glyoxylate aminotransferase (EC 2.6.1.45) and hydroxypyruvate reductase (EC 1.1.1.81) by that of Blackmore \& Quayle (1970), citrate synthase (EC 4.1.3.7) by that of Srere (1969), and malate dehydrogenase (EC 1.1.1.37) by that of Harder et al. (1973). 


\section{RESULTS AND DISCUSSION}

\section{Effect of changing the $C: N$ ratio on cell composition}

Hyphomicrobium $\mathrm{X}$ was grown in a chemostat at a dilution rate of $0.04 \mathrm{~h}^{-1}$. The concentration of the $\mathrm{N}$-source was kept constant $\left(\mathrm{NH}_{4}^{+}-\mathrm{N}=69.9 \mathrm{mg} \mathrm{l}^{-1}\right)$, whilst the carbon source was increased progressively (from methanol-C 240 to $1080 \mathrm{mg} \mathrm{1}^{-1}$ ) to produce a $\mathrm{C}: \mathrm{N}$ ratio (given as $\mathrm{mg}$ carbon per mg nitrogen) range of 3.43 to 15.5 . Over the steady-states studied three distinct growth regimes were recognized. Initially $(C: N$ ratio 3.43 to $7 \cdot 71)$ the cultures were carbonlimited, followed by a dual $\mathrm{C}$ - and $\mathrm{N}$-limitation $(\mathrm{C}: \mathrm{N}$ ratio 8.57 to 11.40$)$ and finally a period of $\mathrm{N}$-limited growth $(\mathrm{C}: \mathrm{N}>11.40$ ) (see Fig. $1 a$ ). The region of dual limitation can be predicted from the following equation:

$$
C_{0} / N_{0}=Y_{\mathrm{X} / \mathrm{N}} / Y_{\mathrm{X} / \mathrm{C}}
$$

(Egli \& Quayle, 1986)

where $C_{0}$ and $N_{0}$ are the carbon and nitrogen concentrations in the feed. $Y_{\mathrm{X} / \mathrm{C}}$ and $Y_{\mathrm{X} / \mathrm{N}}$ are the respective growth yield coefficients based on carbon and nitrogen measured under distinct $C$ and $\mathrm{N}$-limited conditions. When this equation was used with the present data the predicted dual

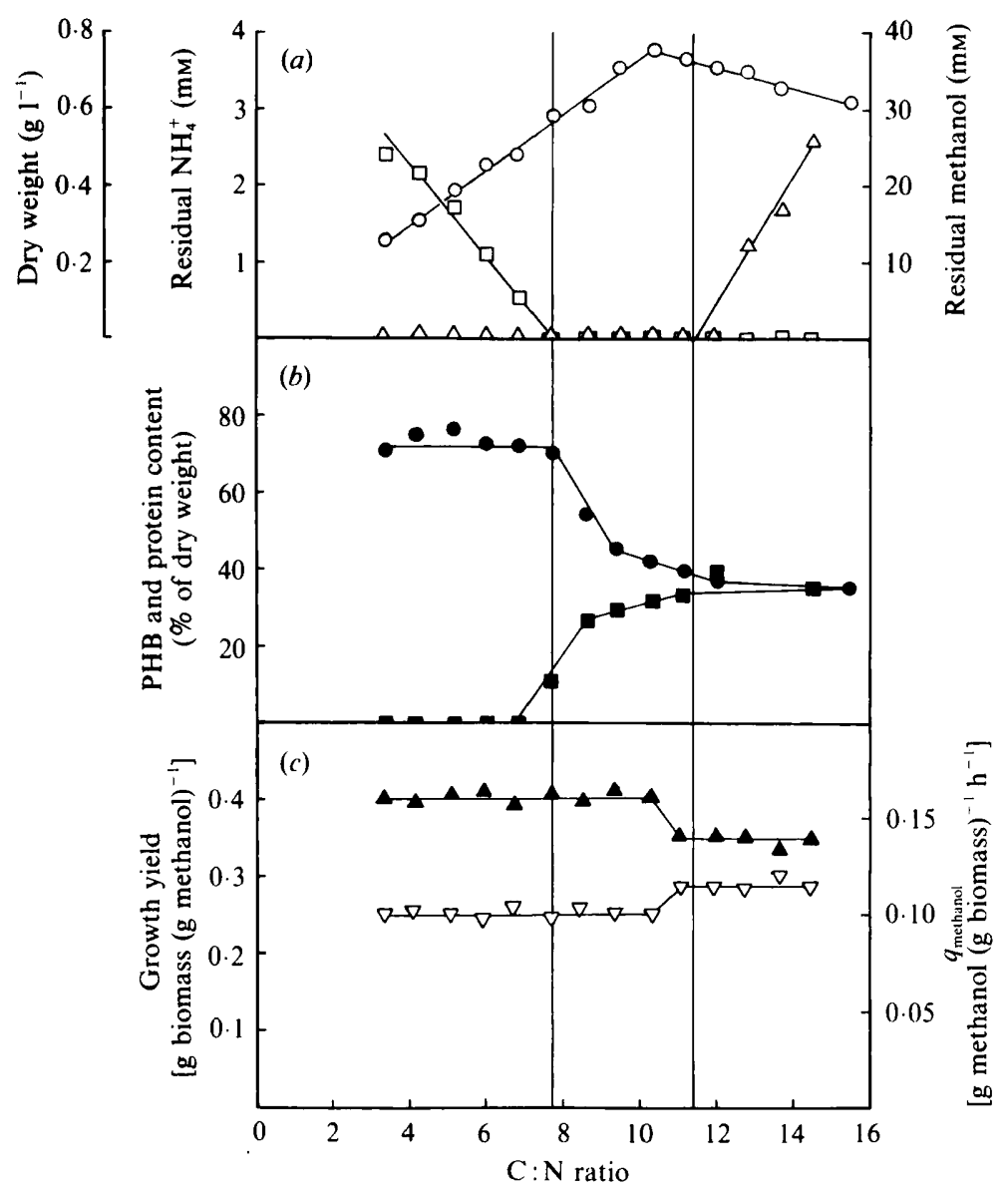

Fig. 1. Growth of Hyphomicrobium $\mathrm{X}$ at a constant dilution rate $\left(D=0.04 \mathrm{~h}^{-1}\right)$ as a function of the methanol-C : $\mathrm{NH}_{4}^{+}-\mathrm{N}$ ratio in the feed. (a) Dry weight of biomass produced (O), residual concentrations of methanol $(\triangle)$ and $\mathrm{NH}_{4}^{+}(\square)$. (b) Cellular content: protein $(\bigcirc)$ and PHB $(\square)$ as a percentage of the dry weight. $(c)$ Growth yield $(\boldsymbol{\Delta})$ and total methanol consumption rate $(\nabla)$. Vertical lines indicate at $\mathrm{C}: \mathrm{N}=7.71$ the end of the $\mathrm{C}$-limited growth and at $\mathrm{C}: \mathrm{N}=11.4$ the beginning of the $\mathrm{N}$-limited growth. 
Table 1. Carbon balances constructed during growth on media with different $C: N$ ratios

\begin{tabular}{|c|c|c|c|c|c|}
\hline $\begin{array}{l}\mathrm{C}: \mathrm{N} \\
\text { ratio }\end{array}$ & $\begin{array}{c}\text { C-input } \\
\text { Methanol-C (feed) } \\
\left.\text { (m-atom } C \mathrm{~h}^{-1}\right)\end{array}$ & $\begin{array}{c}\text { C-residual } \\
\text { Methanol-C } \\
\left(\mathrm{m} \text {-atom } \mathrm{C} \mathrm{h}^{-1}\right)\end{array}$ & $\begin{array}{c}\mathrm{C} \text { in biomass } \\
\text { Cellular- } \mathrm{C} \text { produced } \\
\left(\mathrm{m} \text {-atom } \mathrm{C} \mathrm{h}^{-1}\right)\end{array}$ & $\begin{array}{c}\mathrm{C} \text { in } \mathrm{CO}_{2} \\
\left.\text { (m-atom } \mathrm{C} \mathrm{h}^{-1}\right)\end{array}$ & $\begin{array}{l}\text { Percentage } \\
\text { carbon } \\
\text { recovery }\end{array}$ \\
\hline $\begin{array}{l}5 \cdot 14 \\
9 \cdot 43 \\
13 \cdot 7 \\
14 \cdot 6\end{array}$ & $\begin{array}{l}3 \\
5 \cdot 5 \\
8 \\
8 \cdot 5\end{array}$ & $\begin{array}{l}0 \\
0 \\
1 \cdot 7 \\
2 \cdot 6\end{array}$ & $\begin{array}{l}1 \cdot 58 \\
2 \cdot 92 \\
2 \cdot 92 \\
2 \cdot 73\end{array}$ & $\begin{array}{l}1 \cdot 19 \\
2 \cdot 38 \\
2 \cdot 88 \\
3 \cdot 00\end{array}$ & $\begin{array}{l}92 \cdot 3 \\
96 \cdot 4 \\
93 \cdot 8 \\
98 \cdot 0\end{array}$ \\
\hline
\end{tabular}

limitation phase was $C: N 7.91$ to $C: N 11.30$, which is close to the measured values (Fig. $1 a$ ). These three regimes can be distinguished and further characterized by measuring residual substrate concentrations ( $\mathrm{NH}_{4}^{+}-\mathrm{N}$ and methanol), biomass produced (Fig. $1 a$ ) and the amount of protein and PHB formed (Fig. 1 b). During the initial growth regime $\mathrm{NH}_{4}^{+}-\mathrm{N}$ was detected in the culture filtrate and a linear increase in biomass was observed as the $\mathrm{C}: \mathrm{N}$ ratio increased. The percentage protein in the cells was constant $(70 \%$ with respect to dry wt) and no PHB was detected. During the following phase of C-and $\mathrm{N}$ - dual limitation neither $\mathrm{NH}_{4}^{+}-\mathrm{N}$ or methanol could be detected in the culture filtrate. The percentage protein in the cells decreased whilst PHB was seen to accumulate. This accumulation accounted for the linear increase in biomass throughout this growth phase. Finally during $\mathrm{N}$-limited growth an increasing concentration of methanol was measured in the culture filtrate, with a decrease in the rate of PHB accumulation and a new lower protein content in the cells $(40 \%$ with respect to dry wt; Fig. $1 b$ ). Elemental analysis of the cells supported these changes in the cellular composition. The carbon content of the cells $(48-51 \%$ ) did not change significantly across the range of $\mathrm{C}: \mathrm{N}$ ratios studied, but the nitrogen content dropped from 13.5 to $8.4 \%$ (unpublished results). Throughout the first two growth regimes the specific rate of methanol consumption $\left(q_{\text {methanol }}\right)$ remained constant, but as the growth became $\mathrm{N}$-limited the rate of methanol consumption increased (Fig. 1c). Since the specific rate of carbon assimilation, reflected in the carbon content in the cells, was constant over the range of $\mathrm{C}: \mathrm{N}$ ratios studied, this suggests that more carbon from methanol was channelled into the dissimilatory pathway during $\mathrm{N}$-limited growth. This was substantiated when carbon balances were constructed (see Table 1).

\section{Effect of changing the $C: N$ ratio on the specific activities of the enzymes in the cell}

Nitrogen assimilation enzymes. It has been reported that Hyphomicrobium $\mathrm{X}$ can express both the low and high affinity pathways for $\mathrm{N}$-assimilation (Brooke et al., 1987). When cell-free extracts from steady-state cells were assayed for NADP+-dependent GDH, GS and GOGAT activities the expected regulation of enzyme synthesis was observed. Initially during $\mathrm{C}$-limited growth the $\mathrm{NADP}^{+}$-dependent GDH specific activity increased until the $\mathrm{NH}_{4}^{+}-\mathrm{N}$ in the medium was exhausted. Then the GDH activity immediately decreased to a low but constant level, whilst the GS activity, which was initially low, increased rapidly to a peak of specific activity towards the end of the dual limitation phase of growth (Fig. $2 a$ ). This pattern of specific activity was observed using both the biosynthetic and $\gamma$-glutamyltransferase assay. The use of the transferase assay in the presence and absence of $\mathrm{Mg}^{2+}(60 \mathrm{mM})$ enabled an estimate to be made of the adenylylation state of the enzyme (Shapiro \& Stadtman, 1970). During the C-limited growth phase the enzyme activity was low and the enzyme was highly adenylylated (83-90\%), whereas growth under dual limitation conditions, resulted in a high specific activity level with a lower adenylylation state (30-40\%; Fig. $2 b$ ).

The changes in the specific activity of GOGAT were less dramatic. Initially the enzyme activity was very low but increased linearly to a higher, constant specific activity midway through the dual limitation growth phase. This activity was maintained throughout the Nlimited growth phase.

Enzymes of the $C_{1}$ dissimilation pathway. The specific activity of methanol dehydrogenase, the initial enzyme for both the assimilatory and dissimilatory pathways, changed dramatically over the $\mathrm{C}: \mathrm{N}$ ratio range studied. During $\mathrm{C}$-limitation the specific activity was high but as soon as 


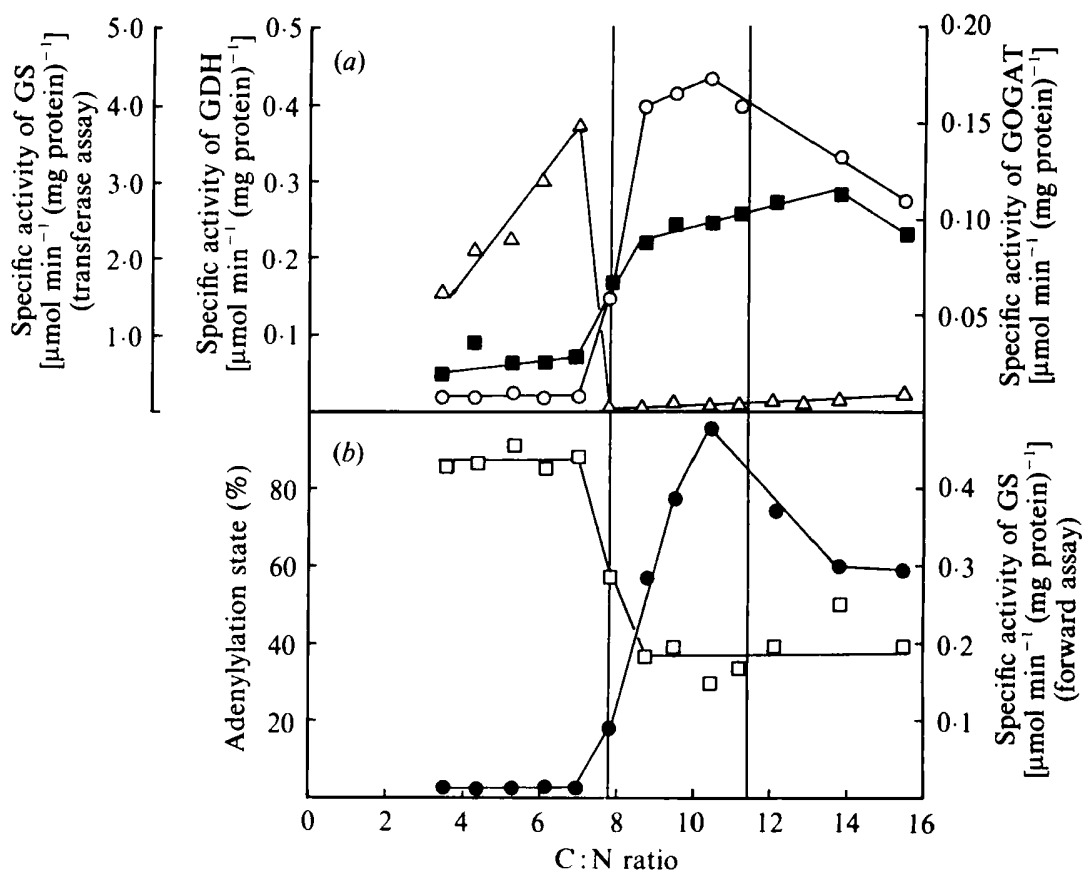

Fig. 2. Specific activities of the enzymes involved in the assimilation of $\mathrm{NH}_{4}^{+}-\mathrm{N}$ in cell-free extracts of Hyphomicrobium $\mathrm{X}$ grown at a constant dilution rate $\left(D=0.04 \mathrm{~h}^{-1}\right)$ as a function of the methanol-C and $\mathrm{NH}_{4}^{+}-\mathrm{N}$ ratio in the feed. (a) $\mathrm{NADP}^{+}$dependent GDH $(\triangle)$, GS $\gamma$-glutamyltransferase assay $(O)$ and GOGAT ( $\square$ ). (b) Adenylylation state (see Methods) of GS ( $\square$ ) and GS forward reaction ( $($ ). For the vertical lines at $C: N=7.71$ and $C: N=11.4$ see Fig. 1 .

the $\mathrm{NH}_{4}^{+}-\mathrm{N}$ was exhausted from the medium the enzyme level immediately dropped to a low but constant value (Fig. 3a). A similar observation has been reported by Jones et al. (1987) with Methylophilus methylotrophus. On the other hand the specific activity of the $\mathrm{NAD}^{+}$-dependent formate dehydrogenase increased during the $C$-limitation growth phase as the $C: N$ ratio increased, and this high level of activity was maintained throughout the subsequent growth. This supports the idea that during $\mathrm{N}$-limited growth the proportion of the carbon $\left(q_{\text {methanol }}\right)$ channelled through the dissimilation pathway was increased.

Enzymes of $C_{1}$-assimilation. Serine glyoxylate aminotransferase and hydroxypyruvate reductase, enzymes specific to the serine pathway, showed biphasic linear increases in their specific activities over the range of $C: N$ ratios studied. The rate of increase in the specific activities was greater during the initial $\mathrm{C}$-limited growth phase. This is consistent with the decrease in carbon assimilated into biomass after the initial growth period (Figs $1 a$ and $3 b$ ). The two non-specific $C_{1}$ enzymes studied showed different specific activity patterns. Malate dehydrogenase activity increased until mid-way through the dual substrate limitation and then remained constant. The specific activity of citrate synthase was low during $\mathrm{C}$-limited growth but increased rapidly through the second phase of growth and remained at a constant but lower activity during the $\mathrm{N}$-limited period of growth (Fig. $3 c$ ).

Carbon balances constructed throughout the experiment showed that no organic compound was produced during growth under carbon excess (Table 1). Under all growth conditions $90-100 \%$ of the methanol-carbon which enters the cells could be accounted for in the biomass, PHB and the carbon dioxide produced.

Thus these results are consistent with findings reported in the literature (Hueting \& Tempest, 1979; Egli \& Quayle, 1986; Gräzer-Lampart et al., 1986) in that when the growth medium was changed from $\mathrm{C}$ - to $\mathrm{N}$-limited a gradual transition occurs involving a phase of dual $\mathrm{C}$ - and $\mathrm{N}$ - 


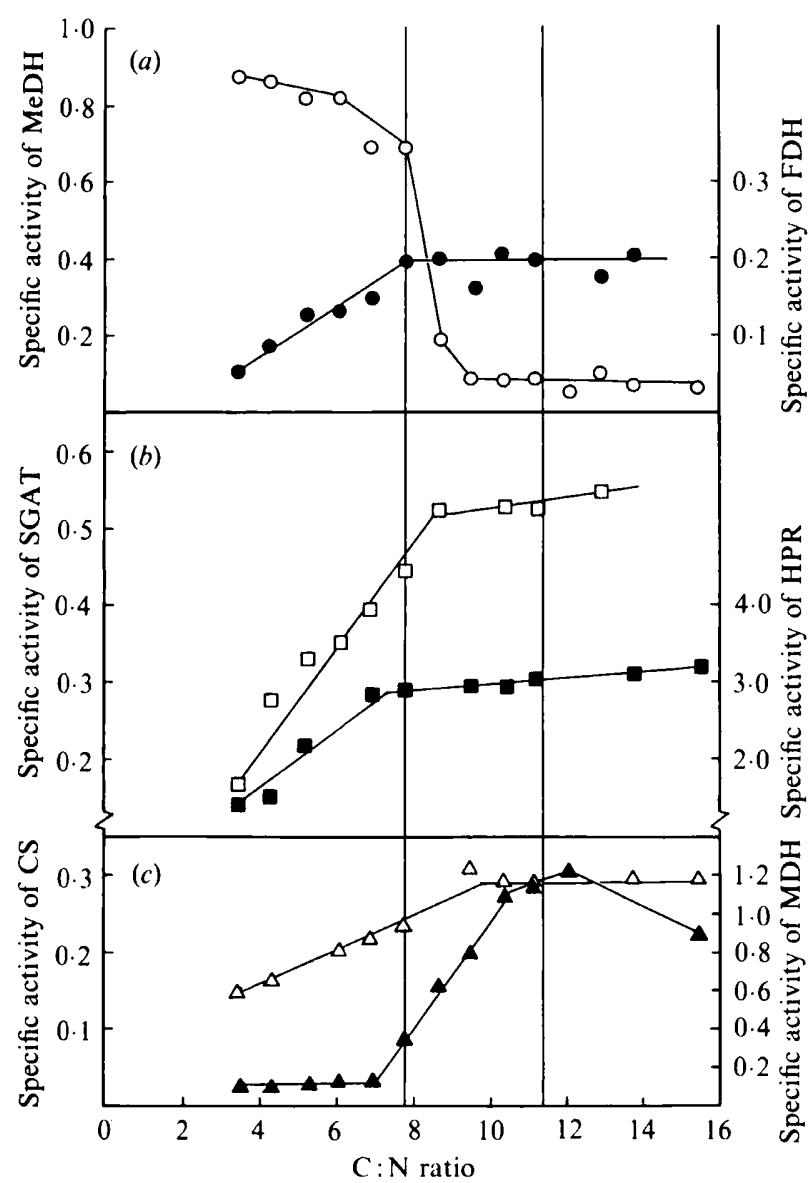

Fig. 3. Specific activities [ $\mu \mathrm{mol} \mathrm{min}^{-1}$ (mg protein $\left.)^{-1}\right]$ of the enzymes involved in carbon metabolism in cell-free extracts of Hyphomicrobium $\mathrm{X}$ grown at a constant dilution rate $\left(D=0.04 \mathrm{~h}^{-1}\right)$ as a function of the methanol-C: $\mathrm{NH}_{4}^{+}-\mathrm{N}$ ratio in the feed. (a) Methanol dehydrogenase (MeDH, $O$ ) and formate dehydrogenase (FDH, O). (b) Serine glyoxylate aminotransferase (SGAT, $\square$ ) and hydroxypyruvate reductase (HPR, $\square$ ). (c) Malate dehydrogenase (MDH, $\triangle$ ), and citrate synthase (CS, $\triangle$ ). For the vertical lines at $C: N=7.71$ and $C: N=11.4$ see Fig. 1 .

limited growth rather than an abrupt stepwise modification. The cellular composition changed from an initial high protein content to one of lower protein content with carbon channelled into PHB. The enzymic changes in the cell reflected the different conditions by $(a)$ a repression of the synthesis of the low affinity $\mathrm{N}$-assimilation pathway and a derepression of the high affinity, but energetically expensive GS/GOGAT pathway, and $(b)$ an immediate decrease in the specific activity of methanol dehydrogenase with a resulting reduction in carbon flux within the cells. The specific methanol consumption rates $\left(q_{\text {methanol }}\right)$ and the carbon balances constructed during the $\mathrm{C}$ - and $\mathrm{N}$-limited growth showed that during $\mathrm{N}$-limitation more carbon is channelled into the dissimilatory pathway, and since all the methanol-carbon taken into the cells can be accounted for in terms of biomass, PHB and carbon dioxide, no carbon was fluxed into other organic over-flow metabolites.

This work was carried out whilst M.G.D. held a SERC research studentship at the University of Sheffield. 


\section{REFERENCES}

Anthony, C. \& Zatman, L. J. (1964). The microbial oxidation of methanol. 2. The methanol-oxidising enzyme of Pseudomonas sp. M27. Biochemical Journal 92, 614-621.

Bender, R. A., Jansen, K. A., Resnick, A. D., BlumenberG, M., FoOR, F. \& Magasanik, B. (1977). Biochemical parameters of glutamine synthetase from Klebsiella aerogenes. Journal of Bacteriology 129, 1001-1009.

Blackmore, M. A. \& QuAYLe, J. R. (1970). Microbial oxidation of oxalate by a route not involving glyoxylate carboligase. Biochemical Journal 118, 5359.

Brooke, A. G. \& AtTwood, M. M. (1985). Regulation of enzyme synthesis in Hyphomicrobium X: growth on mixtures of methylamine and ethanol in continuous culture. FEMS Microbiology Letters 29, 251256.

Brooke, A. G., Duchars, M. G. \& Attwood, M. M. (1987). Nitrogen assimilation in the facultative methylotroph Hyphomicrobium X. FEMS Microbiology Letters 41, 41-45.

Duchars, M. G. \& ATTwOOD, M. M. (1987). NADP+dependent glutamate dehydrogenase from the facultative methylotroph Hyphomicrobium X. FEMS Microbiology Letters 48, 133-137.

EgLI, T. \& QUaYLE, J. R. (1986). Influence of the carbon:nitrogen ratio of the growth medium on the cellular composition and the ability of the methylotrophic yeast Hansenula polymorpha to utilize mixed carbon sources. Journal of General Microbiology 132, 1779-1788.

Gräzer-Lampart, S. D., Egli, T. \& Hamer, G. (1986). Growth of Hyphomicrobium ZV620 in a chemostat: regulation of $\mathrm{NH}_{4}^{+}-\mathrm{N}$ assimilation enzymes and cellular composition. Journal of General Microbiology 132, 3337-3347.

HARDER, W. \& ATTWOOD, M. M. (1975). Oxidation of organic $\mathrm{C}_{1}$ compounds by Hyphomicrobium sp. Antonie van Leeuwenhoek 41, 421-429.

HARDER, W. \& ATTWOOD, M. M. (1978). Biology, physiology and biochemistry of hyphomicrobia. Advances in Microbial Physiology 17, 303-389.
Harder, W., Attwood, M. M. \& Quayle, J. R. (1973). Methanol assimilation by Hyphomicrobium sp. Journal of General Microbiology 78, 155-163.

Herbert, D., Phipps, P. J. \& Strange, R. E. (1971). Chemical analysis of microbial cells. Methods in Microbiology 5B, 304-307.

HuETING, S. \& TEMPEST, D. W. (1979). Influence of the glucose input concentrations on the kinetics of metabolite production by Klebsiella aerogenes NCTC 1418 growing in chemostat cultures in potassium and ammonium limited cultures. Archives of Microbiology 123, 189-194.

Jones, C. W., Greenwood, J. A., Burton, S. M., SANTOS, H. \& TURNER, D. L. (1987). Environmental regulation of methanol and formaldehyde metabolism by Methylophilus methylotrophus. Journal of General Microbiology 133, 1511-1519.

Johnson, P. A. \& QUAYLe, J. R. (1964). Microbial growth on $\mathrm{C}_{1}$ compounds. 6. Oxidation of methanol, formaldehyde and formate by methanol-grown Pseudomonas AM1. Biochemical Journal 93, 281-290.

LAW, J. H. \& SLEPECKY, R. A. (1961). Assay of poly- $\beta$ hydroxybutyric acid. Journal of Bacteriology 82, 3336.

MaRison, I. W. \& AtTwood, M. M. (1982). A possible alternative mechanism for the oxidation of formaldehyde to formate. Journal of General Microbiology 128, 1441-1446.

Meers, J. L., Tempest, D. W. \& Brown, C. M. (1970). Glutamine(amide): 2-oxoglutarate amino transferase oxido-reductase (NADP): an enzyme involved in the synthesis of glutamate by some bacteria. Journal of General Microbiology 64, 187-194.

ShapiRo, B. M. \& StadtMan, E. R. (1970). Glutamine synthetase (Escherichia coli). Methods in Enzymology 17A, 910-922.

SRere, P. A. (1969). Citrate synthase. Methods in Enzymology 13, 3-11.

Tetlow, J. A. \& Wilson, A. J. (1964). An absorptiometric method for determining ammonia in boiler feed water. Analyst 89, 453-465. 